\title{
Sustainable Finance for Landscape Restoration in Spain
}

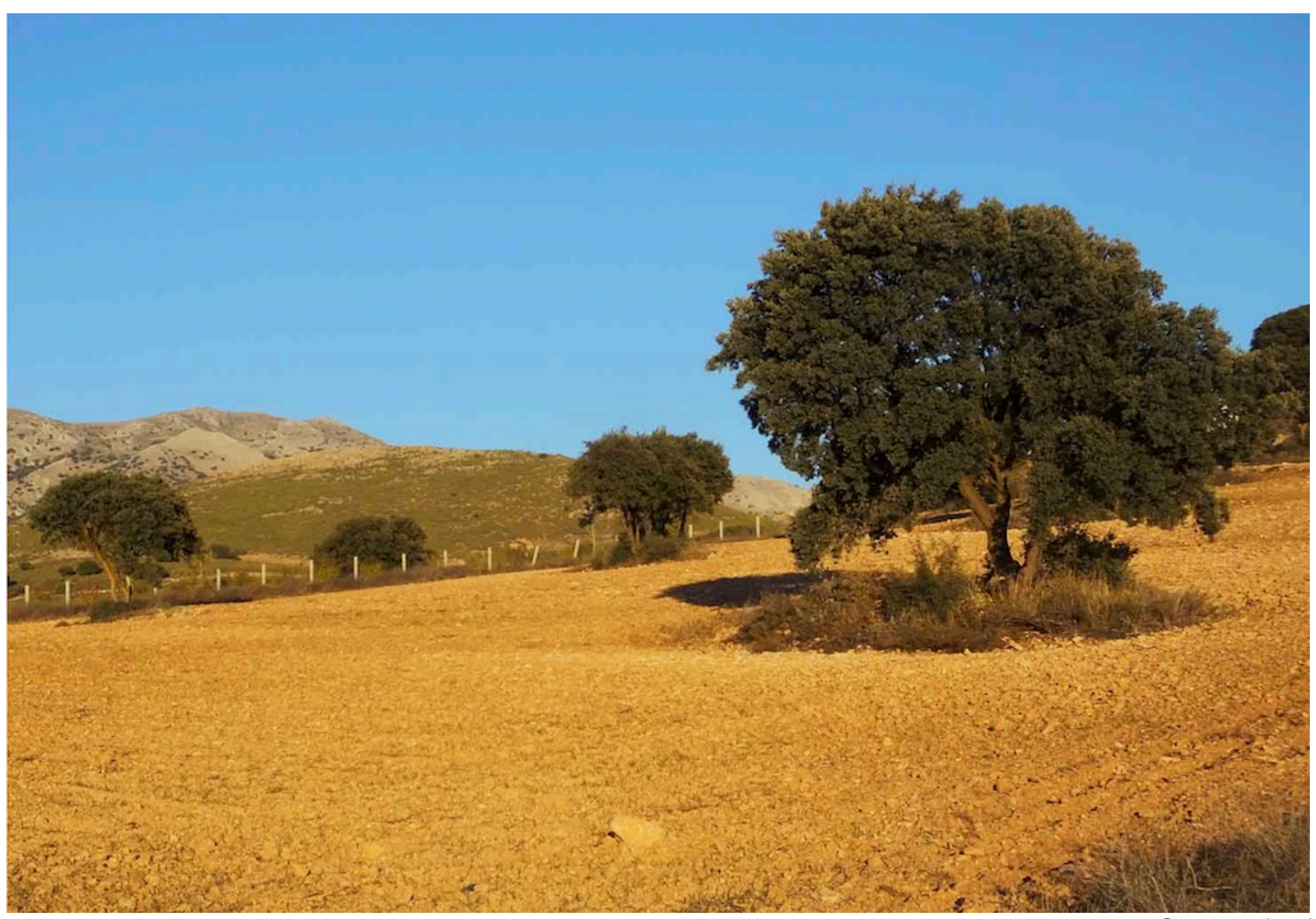

aCommonland 


\section{Introduction}

On a cloudy day in April 2019, William Ferwerda, CEO of Commonland Foundation (hereafter Commonland), paid a visit to Celine van Asselt, chief finance and risk officer at APG Asset Management, one of the largest pension fund investment companies in the Netherlands. Ferwerda had met Van Asselt earlier that month at the Impact Summit Europe 2019. They had agreed to meet again to explore the possibilities for APG to invest in Commonland's landscape restoration initiative in Spain. Hence, this visit.

Commonland was a Dutch NGO devoted to landscape restoration. It had the ambition to restore 100 million hectares of degraded land worldwide by $2040-5 \%$ of the 2 billion hectares of degraded land on the planet. Southern Spain was where one of its major initiatives took place. Commonland had been active in the region for five years. It was now exploring how to scale and finance the existing landscape restoration projects there. Depending on the way forward, a major obstacle could be the lack of long-term large funding. Landscape restoration typically took 20 years or more and Commonland could no longer rely on NGOs' and philanthropists' money only as it had been until now. How to attract investment capital? Ferwerda realised it was about firstly attracting the friendly investors such as philanthropists, angle investors and impact investors, and then moving up the investor-type ladder to attract institutional investors. An interesting, and to Ferwerda promising, option would be to attain funds from APG - a responsible institutional investor with a longterm orientation.

After Ferwerda had arrived at Van Asselt's office and settled in, he began the conversation by telling Van Asselt his personal connection with Spain: During the two and a half decades of travelling to the interior of Spain for ecological work, he had witnessed the on-going landscape degradation and was determined to contribute to positive change there. Spain was once completely forested. When the Romans came 2000 years ago, depletion, deforestation and overgrazing began and it was still continuing. Farmers were leaving their land and migrated to cities to search for work, which led to depopulation and demotivation, in some cases even despair.

\footnotetext{
Tao Yue and Paula Arellano Geoffroy prepared this teaching case under the supervision of Prof. Dr. Dirk Schoenmaker and Dr. Arjen Mulder (Rotterdam School of Management, Erasmus University) and Simon Moolenaar (Commonland). The authors would like to thank Willem Ferwerda, Erica ten Broeke, Roos van der Deijl (Commonland), Frank Ohlenschlaeger (Almendrehesa), Cristóbal Aránega (AlVelAl), Max Berkelmans (Rotterdam School of Management), Celine van Asselt and Jos Lemmens (APG Asset Management) for their input and comments.
}

This case is part of the RSM Sustainable Development Goals (SDGs) case series. It is based on field research and is written to provide material for class discussion rather than to illustrate either effective or ineffective handling of a management situation.

Copyright (c) 2020 RSM Case Development Centre, Erasmus University. No part of this publication may be copied, stored, transmitted, reproduced or distributed in any form or medium whatsoever without the permission of the copyright owner. Please address all correspondence to cdcarsm.nl. 
Ferwerda opened a map of Andalusia on his laptop, showing Van Asselt a territory of 1 million hectares with many small farms dotted on it, and explained that Commonland had made some initial investments in the area in order to help farmers convert to more sustainable and regenerative agricultural practices.

"The farmers love their land and they want to look after it for future generations," Ferwerda said. "Together we can restore the landscape - sustainable practices are crucial for the restoration. As a result, the community would be happier and become more hopeful; the soil quality, water management and biodiversity would improve; the farmer would be reconnected with his land, be inspired by the new practices, and at the same time make a sustainable income, for example by getting a higher price for his regenerative produce."

"Very impressive," Van Asselt said. "How big is a farm there?"

"There is not really something like an average farm size, rather the variation is quite big: farm size can vary from just a couple of hectares up to 1,500 hectares in the case of a professional farmer. In this region, we assume the average farm size is at least 50 hectares."

"That's still very small, and the farms are so many and so scattered," Van Asselt pointed at the map. "There's no way APG or any other investors can oversee what is happening on all those farms. You'll need an intermediary to manage the whole region and be our contact point."

Ferwerda thought for a moment. "We can work on that. Commonland doesn't have the financial expertise, but I'm sure we can find a party to manage the region, structure the financials, and report to APG."

"For any investment, we'll need size, a minimum capital we can deploy, and the right risk returns," Van Asselt emphasised. "The first thing first - size. The opportunity would only be interesting for us, and you can only find an intermediary, if all or at least a vast majority of the farmers would get on board. Can you guarantee that?"

\section{Commonland}

Commonland was founded in 2013 in the Netherlands through a joint effort of three organisations: The Commission on Ecosystem Management at the International Union for Conservation of Nature (IUCN), the Rotterdam School of Management (RSM), and the COmON Foundation.

The way Commonland worked was supporting farmers' initiatives and coestablishing companies with local stakeholders. Together with its regional partners, Commonland had initiated four large projects around the world by 2019: Baviaanskloof-Langkloof in South Africa (550,000 ha); Altiplano Estepario in Andalusia, Spain (1,000,000 ha); the Western Australian Wheatbelt in Australia (300,000 ha); and the Western Peat Meadows in The Netherlands (125,000 ha). 
Through partnering with third parties, Commonland also shared its lessons with those who wished to implement long-term local restoration projects and scale them globally. In 2018, Commonland engaged in partnerships in seven countries apart from the Netherlands, including Haiti, Colombia, Egypt, Zambia, Kenya, Tanzania, and Congo. ${ }^{1}$

To ensure ecosystem recovery and stakeholders' long-term commitment, Commonland developed a 4-returns, 3-zones, 20-years framework (Exhibit 1) as the basis for all its activities.

The 4 returns expected from the restored landscapes were:

1. Inspiration: give people hope and a sense of purpose.

2. Social capital: employment, business activity, education, and security.

3. Natural capital: biodiversity, water and soil quality improvement.

4. Financial capital: long-term sustainable profits.

Exhibit 1: Commonland 4-returns, 3-zones, 20 -years framework

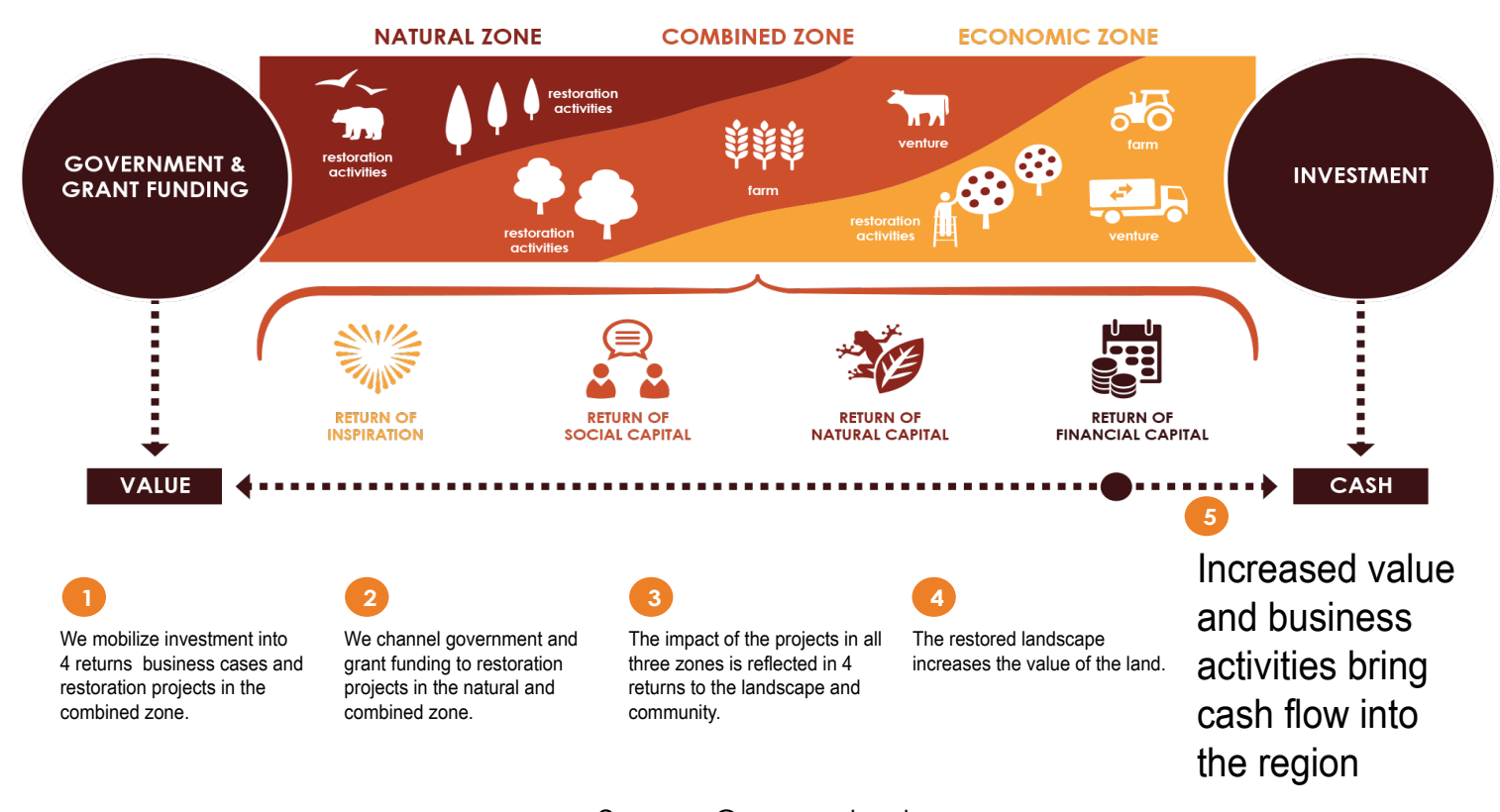

Source: Commonland

In every landscape three geographic zones were distinguished, each with a different balance between economic activity and undisturbed nature.

The first zone is the natural zone. The objective here is to fully conserve and restore the ecosystem so that it could provide all the services it had the potential to provide: rich biodiversity, carbon sequestration, water regulation, and forest products. 
The second zone is the combined zone, where sustainable agriculture is integrated with regenerative practices to retain soil and water. While ecosystems are restored to provide biodiversity and carbon sequestration, sustainable agriculture production serves as the economic drive.

The third zone is the economic zone, designed to process and market sustainable produce from the combined zone and offer a place for tourism activities. Here the 4 returns businesses are located.

\section{The Spanish Initiative}

In 2013 and 2014 Ferwerda visited Spain with his colleague Michiel de Man to search for a place where Commonland could co-initiate a landscape restoration programme. They were looking for a large degraded area where people were inspired by the 4-returns framework. Thanks to Astrid Vargas, a Spanish colleague, they came across the Altiplano Estepario (translated as 'high plateau steppe'; hereafter Altiplano) in Andalusia and Murcia (Exhibit 2).

Exhibit 2: Location of the Altiplano

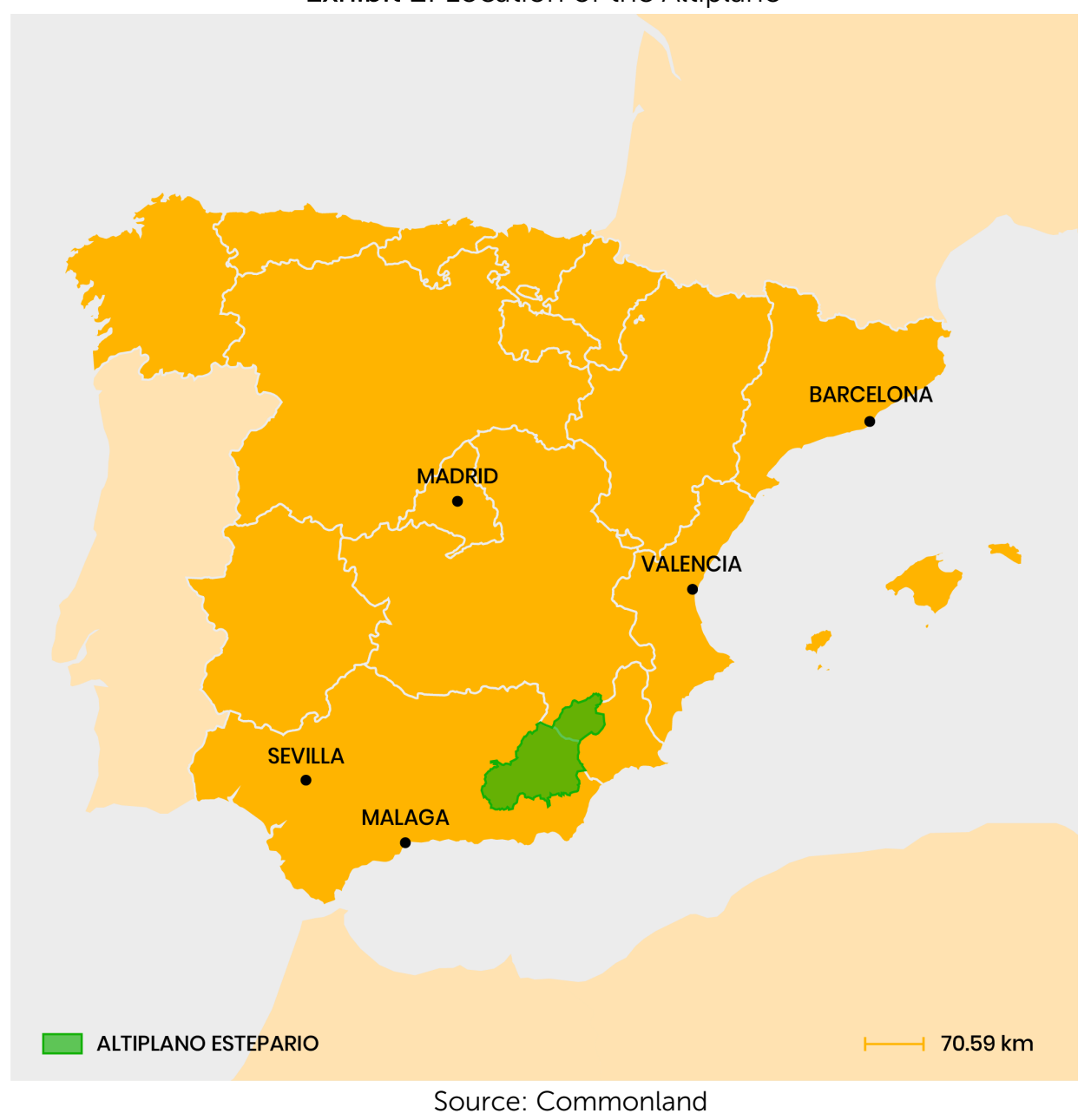


This depopulated countryside - home to 250,000 inhabitants in 2018 - is located in one of the poorest and driest zones of Spain. The area was affected by $40 \%$ unemployment rate, monocroppinga, deforestation, and agricultural subsidy dependency, but also comprises thousands of hectares of natural parks, rich biodiversity and cultural history.

The Altiplano does not consist of one general landscape, but of many specific landscapes where everything is intertwined - desert, greener areas, wetlands along the rivers, trees on the mountain slopes, and populated zones. Forested areas are typically located on the mountain slopes, where productive activity is not possible due to the gradient or the rocky soil.

Land is both public and private. It was important for Commonland to engage and align with local governments, natural park authorities as well as private landowners.

In 2014 Commonland initiated the movement AlVelAl ${ }^{2}$ (hereafter Alvelal) to implement regenerative agriculture at scale, to create the demand for regenerative produce and to restore natural zones on farms and on public land ${ }^{3}$. After four years of combined effort and continued commitment from all stakeholders, the initiative grew to what it was in 2018 (Exhibit 3): 85 farmers actively working with sustainable and regenerative practices on 7,700 hectares of land; 12 direct and 30 indirect jobs created; and 4 business cases identified (almonds, olive oil, compost, and tourism).

The main projects running in 2018 included:

- Restoration of mountain La Muela in the natural park Sierra María Los Vélez with 50,000 trees planted of oaks, juniper, and Aleppo pine species;

- Many farms on the journey towards regenerative farming, where AlVelAl is providing technical advice, workshops and enables pilot projects;

- Commercialisation of high-quality almonds produced by La Almendrehesa (86 tons purchased and commercialised in 2018);

- The touristic project 'Destination Alvelal'4 to promote regenerative agriculture and to develop the supply and value chain of regenerative produce towards touristic centers on the Spanish coast in collaboration with TUI Care Foundation;

- The project 'AlVelAl 8000: Sculptures with life' to restore public land with aromatic herbs in the shape of the famous 8,000 years old cave painting that are iconic for the region.

a A single crop species or cultivar grown as a monoculture. 
Exhibit 3: Alvelal factsheet 2018

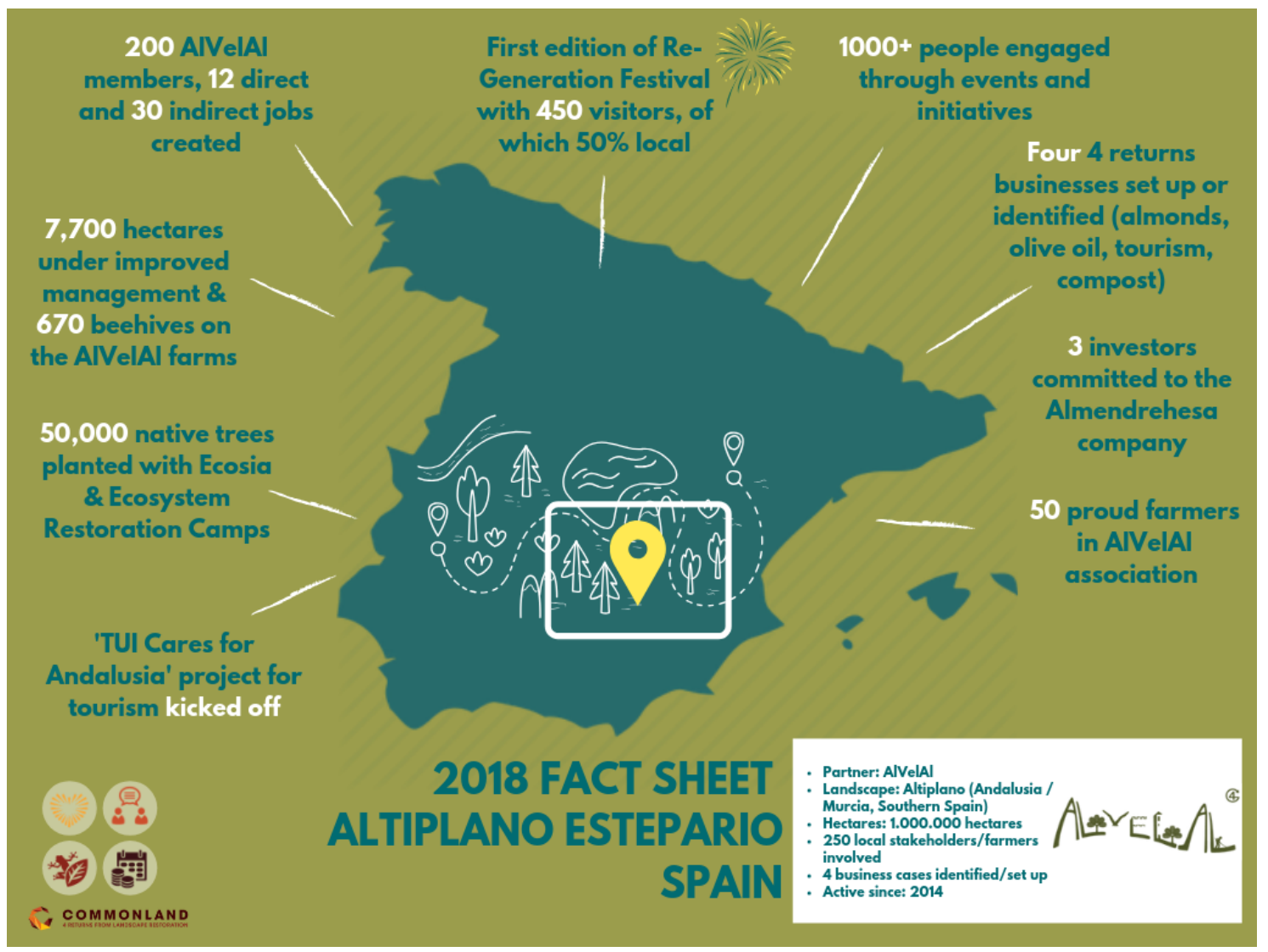

Source: Commonland

\section{La Almendrehesa}

La Almendrehesa was Alvelal's first 4-returns business case. Based on the business case, a farmer-driven trading company of the same name was founded in 2016 to process and market produce from the almendrehesa ecosystem ${ }^{\mathrm{b}}$, firstly focusing on almonds, later on adding other produce such as wine, cereals, honey, aromatic herbs, olives and segureño lamb (Exhibit 4). All of these were produced by farmers of the Altiplano by applying regenerative agriculture practices. ${ }^{5}$ By 2019 the company had 21 shareholder farmers and 8 partnering farmers cultivating 1600 hectares of almond orchards ${ }^{6}$.

The business strategy of La Almendrehesa was two-fold: it offered farmers a higher price for their produce, enabling them to invest in their farms; it also offered clients a high-quality product, which was not only produced following organic principles but actually contributed to landscape restoration.

\footnotetext{
b The almendrehesa ecosystem is an integrated production system: combining almond and endemic trees, with aromatic herbs, cereals, grapes, active bee hiving and lamb farming. Such an ecosystem increases its resilience, decreases erosion, restores the water balance, enhances biodiversity and beautifies the landscape.
} 
Exhibit 4: Almendrehesa integrated production ecosystem based on business cases

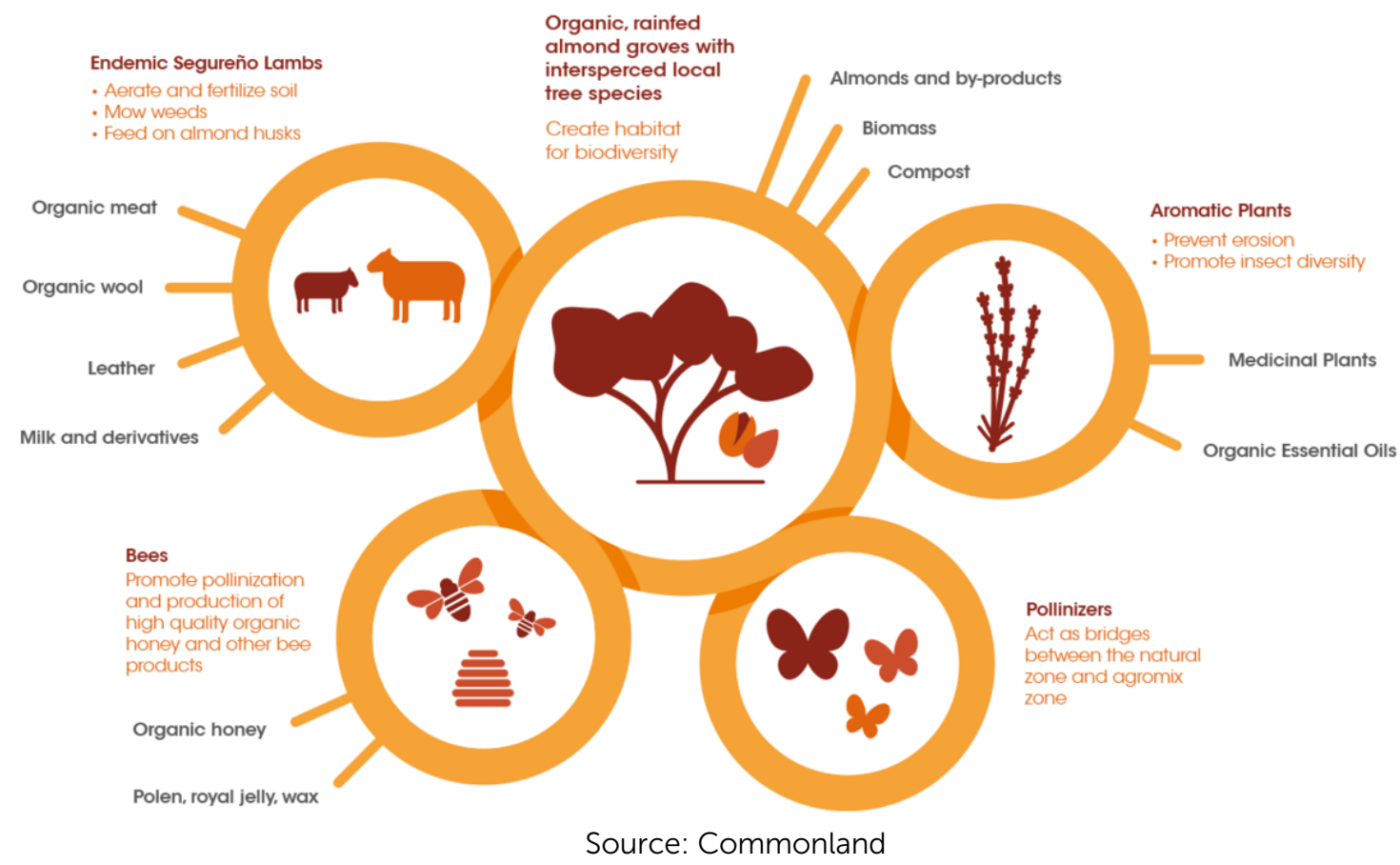

Almonds produced by La Almendrehesa farmers were sold in both retail and wholesale markets. Premium quality, big size almonds were marketed under the retail brand 'Pepita de Oro' (golden seed) primarily in Spain, but also in other countries such as Germany and the UK. The package of Pepita de Oro was made from agricultural waste and renewable resources and 100\% compostable. Smaller almonds entered the wholesale market internationally as diversified products such as roasted almonds, almond oil and press cake meal.

"It is a good moment for our almonds," said Frank Ohlenschlaeger, CEO of La Almendrehesa. "I see there is an increasing demand and some new potential customers like a cosmetic company that look for regenerative products. This is incredible because maybe five years ago people did not know about regenerative farming. Now people are looking for that. I have to find the customers that want to pay for our project and our story."

La Almendrehesa hoped to scale up its regenerative almond turnover from 86 tons in 2018 to 168 tons in 2021, and to 1,000 tons in 2036, which was equivalent to an increase of regenerative almond farming areas from 1,600 hectares in 2018 to 6,000 hectares in 2021 and 24,000 hectares in 2036.

The company was in contact with important market players to distribute its product nationally as well as internationally. It had also attracted some impact investment capital to expand infrastructure, diversify products, set up marketing, and continue restoring the landscape of the Altiplano. 


\section{Scaling and Financing}

Commonland was very hopeful about La Almendrehesa, its first business case in Spain, and wanted to replicate the model with almonds and other regenerative crops such as olive oil, wine and honey in the whole area of the Altiplano (Exhibit 5). In this way, its landscape restoration initiative in Spain could reach more scale and become more interesting for investors of different kinds.

Exhibit 5: Commonland's scaling process

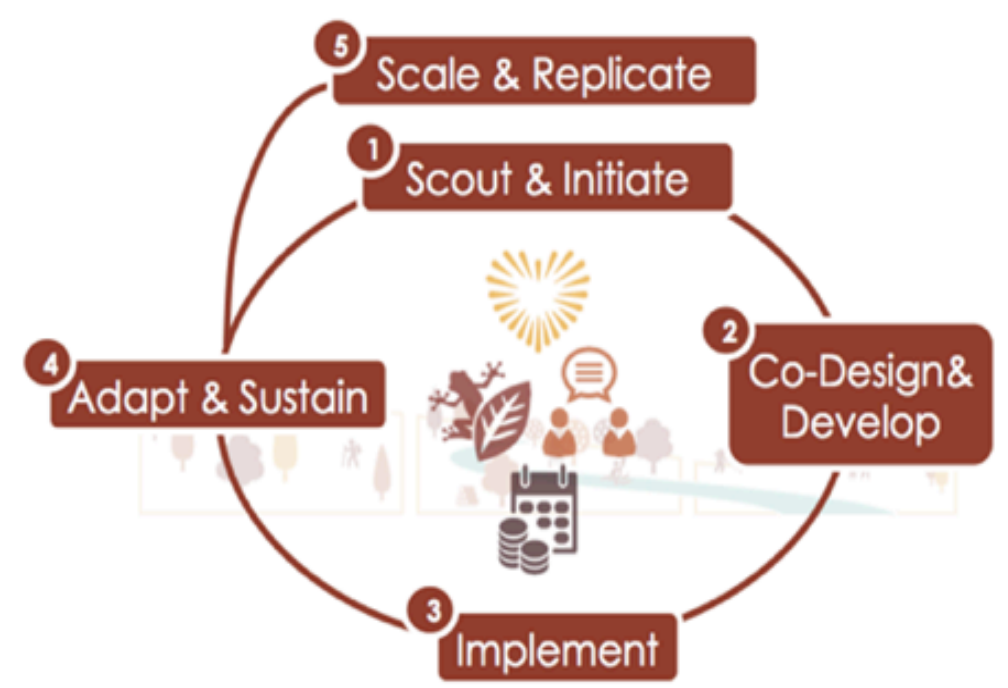

Source: Commonland 4 Returns Impact Report 2018

There were many types of investors out there besides NGOs and philanthropists who were willing to support sustainable landscape restoration initiatives, such as banks, asset management firms, and private funds, and the number was growing. Already in 2017, Rabobank and the UN Environment announced the creation of a 1-billiondollar facility to finance sustainable agriculture using a combination of public and private fundinga. There were already a few examples of landscape restoration initiatives, where investors, businesses, and land users overcame barriers and created commercially viable projects. These examples showed how different investment instruments, such as blended finance, green bonds, and asset class, could offer large amounts of public and private capital options for sustainable land use management at scale .

How could these apparently different worlds of large finance facilities and relatively small business investment opportunities meet in Spain, Ferwerda wondered.

Large-scale landscape restoration projects usually needed four layers of continued financing:

- Initial grants (less than one per cent) to mobilise people;

- Subsidies to get the action on the ground started the first (and subsequent) year(s); 
- Private and public investment after 5 years to scale up the first investments;

- Private and public investments for the long-term run of the whole project.

Commonland based its funding model (Exhibit 6) on these four layers and was aiming to use blended finance mechanisms to fund the scaling of its initiative in Spain. Different types of investors with different expectations and goals could together reduce the risk of investment.

Exhibit 6: Commonland funding model

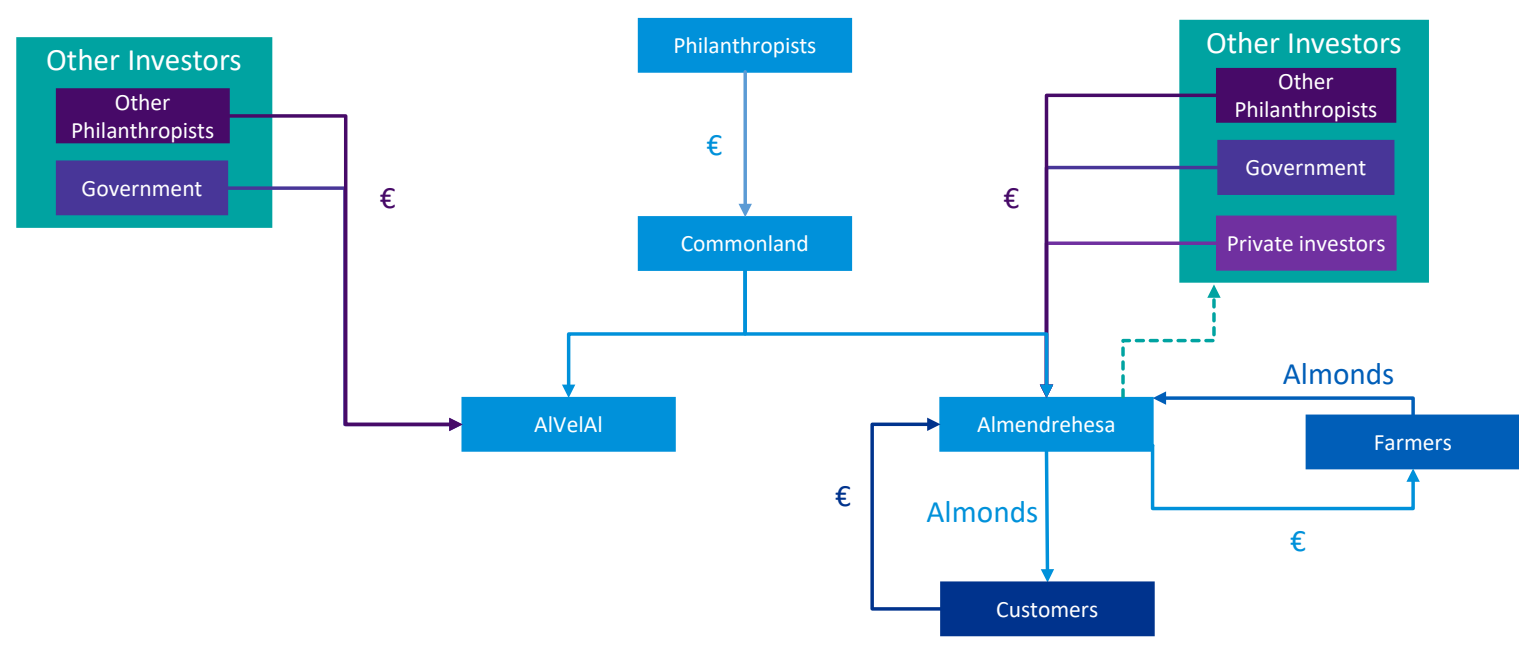

Source: Commonland

Reflecting on the opportunities, Ferwerda said: "To mobilise mainstream finance into our sector we will need to think differently. We will need to view land restoration as an industry like the health or food or infrastructure industry [...] We must think holistically because we are talking about millions of hectares, areas the size of countries that will take decades to recover. If we calculate well the values of social and environmental returns per hectare, we will show the potential to increase the value of the land. If we can extrapolate these numbers to private investors and local governments, I know the numbers will convince them."

\section{Integrated Value for Farmers}

In order to convince these investors to put money in Spain, Commonland would need to begin with monetising the tangible as well as the intangible values of landscape restoration in Spain. The best way to approach this was to recognise integrated value (the total sum of financial, social and environmental capitals), include them in the cash flows and adjust them by risks in time.

What would it mean for farmers financially if they converted to sustainable and regenerative agricultural practices? Ferwerda and his team had made some initial 
calculations of cash flows at the farmer's level (see Spreadsheet), basing their assumptions on an average farm that followed the La Almendrehesa regenerative agricultural concept and delivered almonds to the Almendrehesa trading company.

The typical farm had 50 hectares of land, $70 \%$ of which was used for farming and the rest was forest. The operating period was 30 years with the first 5 years as the initial investment period. In this initial period, the farmer would invest in regenerative farming (both land and trees) but would not see any return until the $6^{\text {th }}$ year.

His/her investments in the first five years would include:

- Trees (almonds): $€ 1,000 /$ ha in Year 0 , and another 50\% ( $€ 500$ per ha) in Year 1.

- Other (e.g. land maintenance): $€ 1,000 /$ ha in Year 0, then linearly declining in the next four years (Year 1: 75\%; Year 2: $50 \%$; Year 3: 25\%).

- From Year 4 onwards, the land would only need labour.

Although investments were concentrated in the first five years, the farmer could anticipate reinvestments down the line because almond trees only live 20-25 years.

Reinvestments would include:

- Trees (almonds): Year 20 at 75\% of the Year 0 investment.

- Other: Year 20 at 50\% of the Year 0 investment; Year 21 at 50\% of the Year 1 investment.

After the first five years of investment period, the farmer could expect gradually increased income from various sources:

- Selling crop: In the first year of harvest (Year 5), the farmer could expect an income of $€ 1000 /$ ha. From Year 6 and onwards he/she could expect an income growth at $4 \%$ per annual (depending on weather).

- Markup through Almendrehesa: The assumption is that farmers could sell their organic regenerative almond produce at a premium of $10 \%$ higher price than regular organic produce.

- Ecosystem-services (PES: 'paying for ecosystem services'): The farmer could receive additional payment of $€ 100 /$ ha/year from selling land access to tour operators (€40/ha/year) and watershed services to municipalities and other governmental organisations ( $€ 60 /$ ha/year).

- $\mathrm{CO}_{2}$ certificates: The farmer could capture on average 2 tonne $\mathrm{CO}_{2} /$ ha/year on his/her land and issue $\mathrm{CO}_{2}$ certificates for $€ 25$ a piece.

During the land restoration period (Year 0-4), the farmer would not generate any income. To offset this, a $€ 25,000$ loan would be needed. The investments were funded through additional amounts (see Spreadsheet) and could be structured as below:

- Interest rate: $4 \%$ per annum

- Amortisation period: 25 years 
- Years 0-5: The farmer would neither pay interest nor amortise the loan.

- Years 6-30: He/she would pay interest on loan outstanding, and linearly amortise the loan.

The farmer would also need reserve $50 \%$ of the first year's total investment as a working capital buffer, packed at an ESCROW account. If needed, the working capital buffer could be used to fill in any financing gaps (due to unpredictable weather and other events) and the remaining working capital could be used to fund the last amortisation of the loan (Year 30).

Based on the above, Commonland already foresaw stable and positive cash flows for farmers. Ferwerda was confident that this portfolio of small land restoration projects would be potentially interesting for mainstream investors. The only thing he was not sure about was whether these projections were financially strong and safe enough to convince all the farmers to take on regenerative agriculture based on the Almendrehesa concept and deliver their produce to the Almendrehesa trading company.

\section{What Next?}

Inside the APG office, the conversation between Ferwerda and Van Asselt was going well. Van Asselt emphasised that responsible investment was important for APG: "Our clients want us to invest responsibly, want to contribute to the SDGs, so intrinsically I want that too and the 4 returns seems to provide that... But the better Commonland can monetise that, the easier it is for us to step in. We see the trends with our clients, especially the younger participants who are very open to it [responsible investment]; the older ones are less open. It's also a matter for us to have courage, look for the long term, and to be sure that participants understand what we do, because it is our fiduciary duty [to care for our pension funds], it's not our money, but their money."

"Since we don't have the expertise ourselves in land restoration, we would need somebody to do that for us," she continued. "Somebody who knows the operations, but also who knows the financials, who is able to speak to institutional investors, who has track record - experienced in setting up a vehicle for an investor, and who knows how to report to us."

"We'll start looking for such an expert to be the intermediary," Ferwerda said, "and meanwhile, we'll continue working on the financials for the farmers and within the landscape as a whole. The projections so far did not look bad. But we still need look at the calculations closer up, adjust our assumptions if needed, so that we can have the best proposal for the farmers. The proof of financial viability at the local level is the cornerstone of everything. We have to get it right."

Being trained as an ecologist who frequented Andalusia for the past 25 years and who spoke fluent Spanish, Ferwerda understood the local farmers' hesitation in taking on sustainable and regenerative practices. It was because they had been 
taught conventional farming by their fathers, and their fathers by their fathers... The farms were their livelihood - changing what they had been doing for centuries was considered a financial risk for them.

Even more so due to the ever more extreme climatic conditions, water scarcity and soil degradation. The financial risk for the farmers should be shared to facilitate a full transition. Already, the first farmers had reset their mindset and saw that they could have multiple returns in a different way. A mindset change at a larger scale was necessary for landscape restoration to occur and inevitable for the farmers' and communities' survival.

The first and bridging step towards a mindset shift was to show the farmers that sustainable and regenerative practices were not just beneficial for the environment and society in Andalusia, but made good business-sense as well. This could help farmers to embark on the implementation of new practices and would at the same time lay the foundation to engage other stakeholders and institutional investors like APG, which could set up an aggregate fund from which the smaller land restoration projects could be financed.

Ferwerda and Van Asselt agreed to meet again in two weeks. By then Commonland would have the farmer's financials carefully analysed and Ferwerda would be able to discuss a concrete proposal with Van Asselt. There was a lot of work to be done but Ferwerda left the APG office invigorated. He saw the hope to scale up landscape restoration - not just in Spain but also on billions of hectares elsewhere on the earth. 
Appendix: Organic farm La Junquera and Regenerative Academy in Murcia

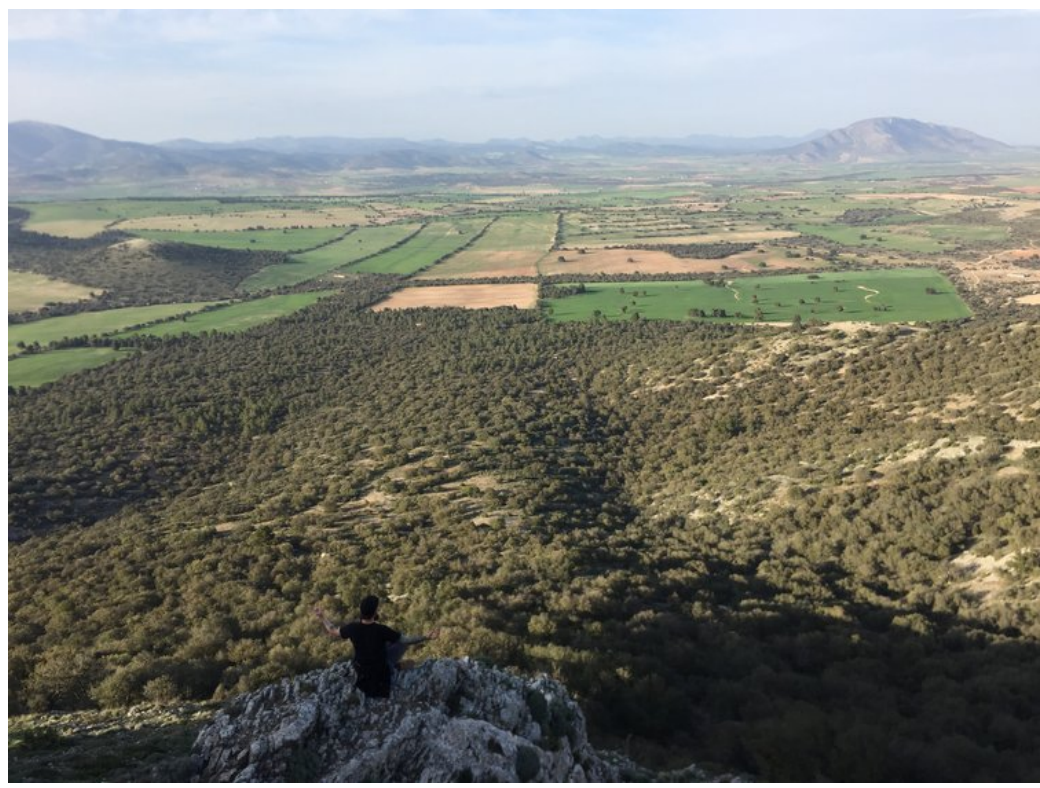

La Junquera is one of the largest Alvelal members' farms. Owned by 30 -year-old Madrid native Alfonso Chico de Guzmán since 2012, the farm consists of 1100 hectares located $70 \mathrm{~km}$ west of Murcia, the city that gives its name to the whole province.

Characteristics of this region are the semiarid climate, the very low precipitation, the mountainous terrain with an average of 1000 meters high, and the sparse population. The agriculture in the province is based on cereals, rainfed almonds, olives and the local 'Segureño' sheep breed.

Experiencing the serious erosion and desertification ${ }^{c}$ problems of southern Spaindesertification threatens $75 \%$ of Spanish territory and $90 \%$ of Murcia province ${ }^{7}-$ Chico de Guzmán has been implementing farming techniques adapted to climate change, erosion, and the extreme dry conditions of Murcia. By introducing 'regenerative' practices such as building silt traps and ponds, limiting tilling, carving swales to collect rainwater and sediment traps to catch nutrient-rich topsoil, he is trying to restore the soil's health, hold back the advancement of the desert, and bring back life to La Junquera village. "This farm has been in my family for five generations... But climate change is affecting this area quite fast. Part of the soil was very badly eroded. We were hitting bedrock when we were digging under the topsoil," 8 recalls Alfonso, who says soil loss in his farm reaches 40 to 50 metric tons per hectare per year, about the double of the region's average.

La Junquera has been slowly transformed into a beacon of regenerative agriculture in Southern Spain according to the 4-returns principles of Commonland. Currently, the main organic commercial crops in the farm are cereals (500 ha) and almonds (300 ha). There is also production of pistachio (6 ha), walnuts, apples, cherries, grapevines and vegetables. About 300 hectares have diverse natural zones, some of them steep, rocky, densely forested, bare or degraded.

\footnotetext{
c Desertification is a type of land degradation in which a relatively dry area of land becomes a desert, typically losing its bodies of water as well as vegetation and wildlife.
} 
In the centre of La Junquera is the Regeneration Academy, a young organisation created with the aim to offer "a transdisciplinary learning environment for those people and organisations who want to co-create the future of farming and food." 9

For the academy, regenerative agriculture and land use is an essential part of its future food system. The academy works with young professionals, students and entrepreneurs, rural communities, universities, institutes and organisations connected to regenerative agriculture and ecosystem restoration.

The farm and the academy coexist in symbioses: the farm facilitates land and infrastructure, while the Regeneration Academy helps the farm make better decisions on restoring landscape, biodiversity and sustainable profit. "Conventional farming practices are causing many problems in the region which is already one of the poorer regions in Europe. On a farm level, this means soil erosion and decreasing fertility, decline of biodiversity, lack of water (both drinking and farm use). On community level, this means rural abandonment because of lack of possibilities, greying, outmigration, and a lack of inspiration among young people... Regenerative practices not only help to reduce erosion, improve fertility and increase water infiltration, but also increase dramatically the biodiversity," ${ }^{10}$ says the academy.

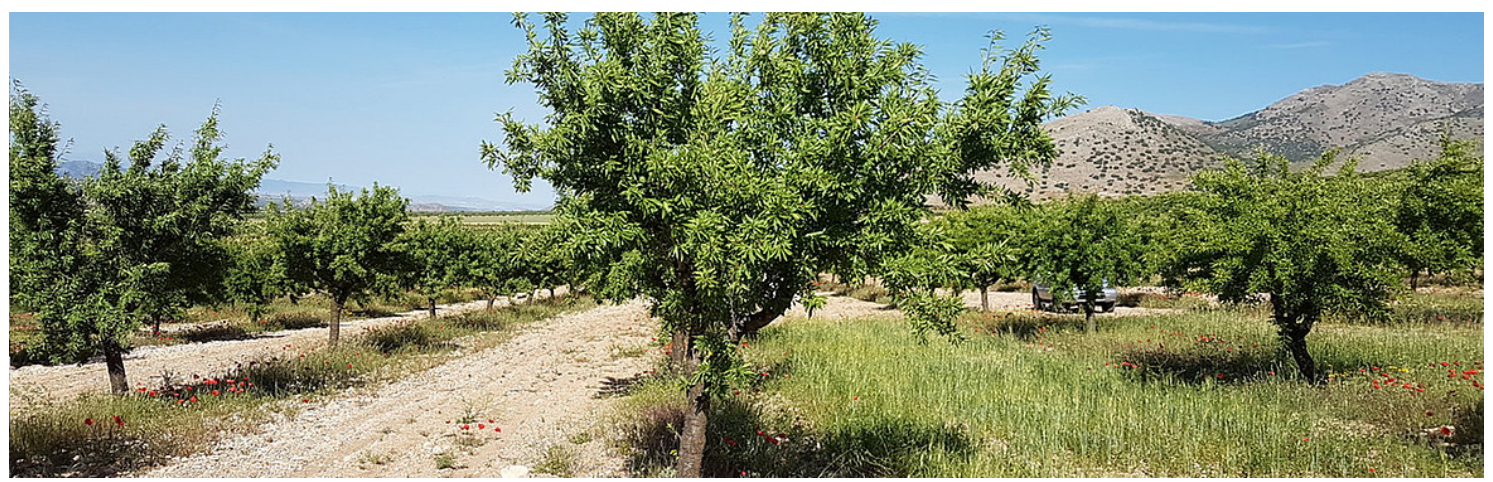




\section{Endnotes}

${ }^{1}$ https://www.commonland.com/en

2 https://www.alvelal.net/proyectos

3 https://4returns.earth/portfolio-items/rebuilding-the-landscape-by-building-a-movement/

${ }^{4}$ https://www.tuicarefoundation.com/en/media/news/the-future-of-farming-isregenerative-tuicarefoundation-andalusia

5 "La Almendrehesa S.L. 4 Returns $®$ trading company in Southeastern Spain," internal document.

${ }^{6}$ http://almendrehesa.es/

${ }^{7}$ https://www.eca.europa.eu/Lists/ECADocuments/SR18_33/SR_DESERTIFICATION_EN.pdf

8 POLITICO Europe Edition March 2019. https://www.politico.eu/article/farmer-sand-spainfight-against-desertification-soil-degradation/

${ }^{9}$ https://www.regeneration-academy.org/about-us

10 https://www.regeneration-academy.org/the-farm 